\title{
Application of the Electrical Resistivity Tomography and Seismic Refraction Methods for Groundwater Investigation in Savannakhet Province, Laos
}

\author{
Viengthong Xayavong ${ }^{1,2}$, Minh Duc $\mathrm{Vu}^{1,{ }^{*}}$, Duong Anh $\mathrm{Nguyen}^{3}$, Tuan Minh $\mathrm{Vu}^{3}$, Chung Anh \\ Do ${ }^{4}$, Luan Thanh Pham ${ }^{1}$, Ahmed M. Eldosouky ${ }^{5}$
}

${ }^{1}$ University of Science, Vietnam National University, 334 Nguyen Trai, Hanoi, Vietnam.

${ }^{2}$ Physics Department, Faculty of Natural Science, National University of Laos, Dongdok Campus 7322, Vientiane, Laos.

${ }^{3}$ Institute of Geophysics, Vietnam Academy of Science and Technology, 18 Hoang Quoc Viet, Hanoi, Vietnam.

${ }^{4}$ Institute for Ecology and Works Protection, Vietnam Academy for Water Resources, 171 Tay Son, Dong Da, Hanoi,

Vietnam.

${ }^{5}$ Geology Department, Faculty of Science, Suez University, Suez, 43518, Egypt

\section{ARTICLE INFO}

Article history:

Received 8 November 2021

Received in revised form 26 November 2021

Accepted 27 November 2021

Available online 27 November 2021

\section{Keywords}

Electrical resistivity tomography (ERT),

Seismic refraction explorations,

Groundwater,

Aquifers,

Laos. \begin{abstract}
The hydrogeology information can be revealed from subsurface physical property contrast values through integrated geophysical exploration techniques. The major objective of this research work is to delineate fresh groundwater zones in Savannakhet province through application of electrical resistivity tomography (ERT) and seismic refraction methods. The results obtained from these methods showed that the moderate resistivity regions vary from $15-60 \mathrm{Ohm} . \mathrm{m}$ found at the depth of $16-20 \mathrm{~m}$, is considered as suitable areas for good groundwater potential areas whereas the seismic velocities distribution analysis ranging from $1200-1800 \mathrm{~m} / \mathrm{s}$ found at the depth of $16-20 \mathrm{~m}$, is considered as groundwater table level. These results also agree well with information obtained from two boreholes in the Outhoumphone district, where samples at depth of 16 to $20 \mathrm{~m}$ have been identified as sandstone and siltstone. The geophysical results also verify that the ERT and seismic refraction methods can be an efficient tool for groundwater evaluation in Savannakhet province and integrated geophysical techniques can be used for groundwater evaluation in other similar geological areas in Lao PDR.
\end{abstract}

\section{Introduction}

Groundwater is an essential source of freshwater, which is important for domestic usage purposes in some rural areas in Laos. However, many parts of Laos have serious water issues both in quantity and quality such as far from surface water, groundwater dry out in the dry season and poor groundwater quality. Thus, groundwater is an alternative source to supplement water supply for agriculture, irrigation, industry, and household. Whereas groundwater information is limited for monitoring and evaluation activities regarding quantity and quality of groundwater have not yet been carried out to any significant degree. In addition, Laotian commonly use shallow hand dug wells at 5 to $10 \mathrm{~m}$ depth, which are not biologically safe sources and usually dry out during the dry season, and poor groundwater quality due to infiltrations of domestic waste and from farm animal [1,2]. In Savannakhet province, information and programs for the monitoring and evaluation of groundwater quantity and quality are limited.

\footnotetext{
${ }^{*}$ Corresponding authors at Vietnam National University E-mail addresses: minhvd@vnu.edu.vn (Minh Duc Vu)
}

Over 100 boreholes were drilled in the area with about 50 to $60 \%$ boreholes can produce good quality wells, and about 50 boreholes have been selected for production wells due to poor water quality [3].

The ERT method has been widely used for groundwater explorations, this technique can determine depth and thickness of various earth layers and groundwater potential zones or aquifers from observed earth electrical resistivity. However, there is ambiguity in interpreting the earth resistivity regions values. Low resistivity values can either indicate higher clay content or higher water content. The results of seismic refraction in term of seismic velocity models may be able to reduce the ambiguity. Therefore, it will be of great benefit if we apply the geophysical methods, especially electrical resistivity tomography and seismic refraction explorations for groundwater investigation and management in Savannakhet province. A range of different methods and software have been developed to delineate subsurface structures at high precision and accuracy [4-7]. Recently, integration of electrical resistivity tomography and seismic refraction methods are the most widely applied for determining reliable subsurface earth structures to many 
different objectives of the research in many different countries around the world, including groundwater investigation [8-10]. However, these geophysical methods have not been widely used yet in Savannakhet province.

The objective of this work is to determine locations of groundwater potential zones and depth to aquifers by using ERT and seismic refraction methods in Savannakhet province. The obtained results are compared to groundtruth from boreholes, including the soil samples information.

\section{Geological setting}

The two research areas, namely the Outhomphone and Champhone districts, are located in Savannakhet province, Laos. In this article, the study area selected for presentation is only the Outhomphone district where is situated in the northwestern part of the province with elevation between 175 to $200 \mathrm{~m}$ and most areas are covered by rice farm and forests. The annual rainfall is estimate $1780 \mathrm{~mm}$, but it depends on regional parts [12].

The geology of the study area is reported by many researchers such as the Savannakhet basin where geology is considered as an extend part of the Sakon Nakhon basin in northeast part of Thailand. The PhuPhan range divides Khorat Plateau into two basins such as the Khorat basin in the south and the Sakon Nakhon basin in the north. These basins cover area of about $36,000 \mathrm{~m}^{2}$ and $21,000 \mathrm{~m}^{2}$ respectively (Fig. 1) $[12,13,14]$. On the other hand, these basins are similar geological information to the Maha
Sarakham Formation, which consist of claystone, shale, siltstone, sandstone, anhydrite, gypsum, potash, and rock salt $[15,16]$.

The selected research site is an active economic and population is growing and related to the increasing quantity water in the research area, but there are no mechanisms for data collection, compilation and storage, no protocols or entities tasked with the implementation of new groundwater resources.

\section{Methods}

\subsection{Resistivity measurement}

The aims of electrical resistivity survey are to measure the resistivity distribution in the subsurface layers by conducting measurements along the ground surface. The electrical resistivity tomography method is an important geophysical exploration method used to provide a highresolution earth subsurface image of the electrical resistivity values. The earth resistivity values vary greatly due to different subsurface geological information. The various geophysical exploration techniques distinguish subsurface when a contrast exists in their electrical properties. The earth resistivity depends on porosity, permeability, saturated water and the concentration of dissolved solids in pore fluids within the earth subsurface layers (Table 1) [17]. The earth electrical resistivity of clean sand, saturated aquifer can be expressed via Archie's law:

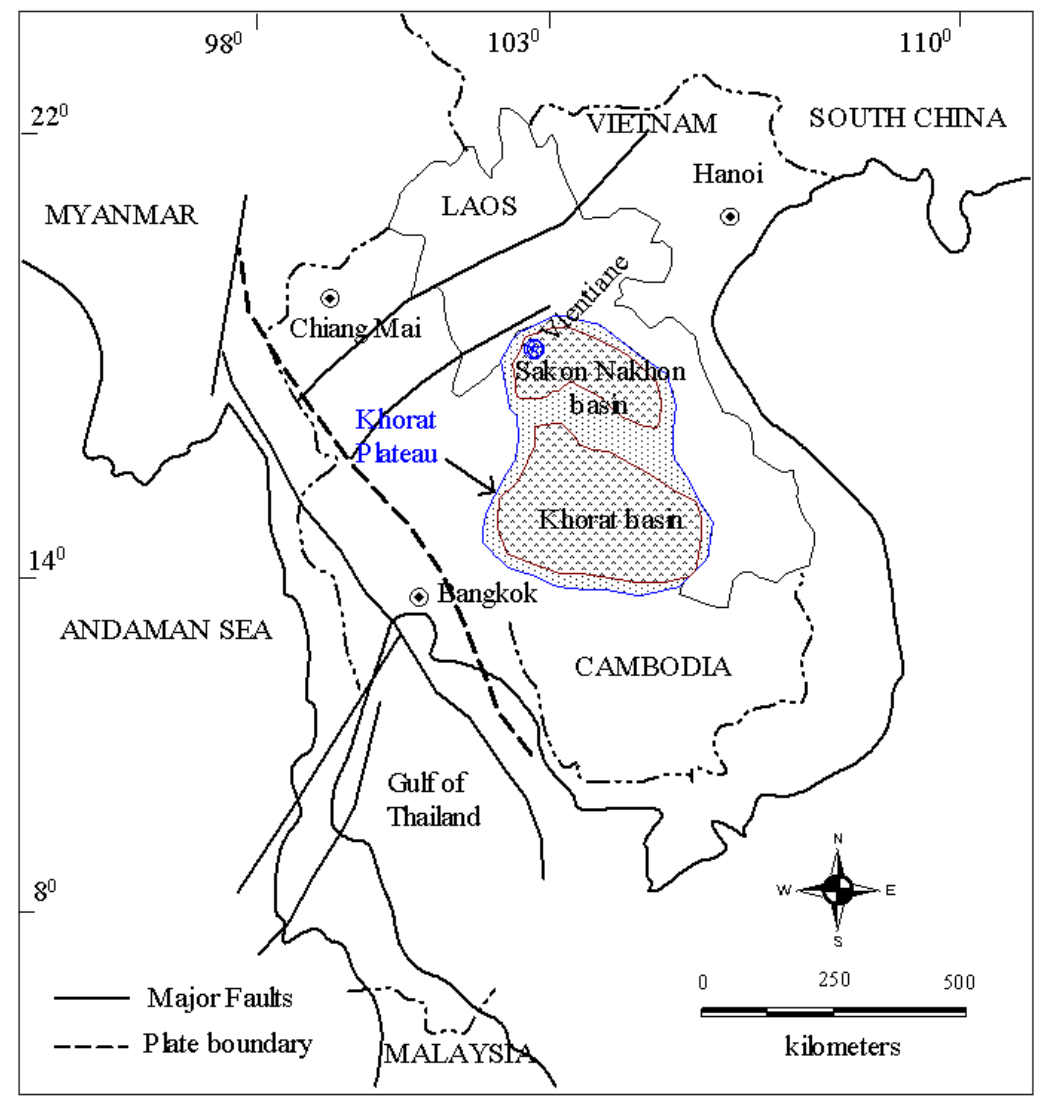

Fig.1. Map of the Khorat and the SakonNakon basins in the Khorat Plateau [11] 


$$
\rho_{r}=a \rho_{w} \phi^{-m}
$$

Where: $\rho_{r}$ is resistivities of rock

$$
\rho_{w} \text { is resistivities of rock water }
$$

$a$ is the saturated coefficient $(0.6<a<2.0)$

$m$ is the cementation factor $(1.3<m<2.2)$

$\phi$ is fractional porosity

Table 1: Typical electrical resistivity values for various earth materials $[17,18]$

\begin{tabular}{lcc}
\hline \multirow{2}{*}{ Earth materials } & \multicolumn{2}{c}{ Resistivity values (Ohm.m) } \\
\cline { 2 - 3 } & {$[17]$} & {$[18]$} \\
\hline Clay & $1-100$ & $1-100$ \\
Sand & $60-1000$ & $50-1050$ \\
Gravel & $100-5000$ & $600-10^{4}$ \\
Mudstone & - & - \\
Siltstone & $20-150$ & - \\
Shale & $20-2000$ & $2-2000$ \\
Sandstone & $10-5000$ & \\
Sandy clay & $30-215$ & \\
Alluvium & $10-800$ & \\
Groundwater & $10-800$ & \\
Fresh groundwater & $20-160$ & \\
Salt water & 0.25 & 0.2 \\
\hline
\end{tabular}

The 2D electrical resistivity measurement is conducted by injected current into the earth subsurface through the two current electrodes and measures the potential difference at the other two potential electrodes on ground surface. The commonly electrodes arrays of $2 \mathrm{D}$ resistivity measurement are usually arranged in a linear array. The apparent resistivity is known as the bulk average resistivity of earth subsurface layers affecting the current. The apparent resistivity can be calculated by the ratio between the measured potential difference and the input current, and multiplying by a geometric factor for the specific array will be used in the 2D data acquisition [18]. In this work, Wenner electrode array (Fig. 2) was selected to use for 2D resistivity data acquisition. These data were measured by manually and automatically by using the ABEM Terrameter SAS 1000. The data integrated in the research area was processed by Earthlmager software in order to determine an earth resistivity model that estimates the actual subsurface layers, the median depth of surveying is estimate 0.52 times the electrode spacing for the Wenner electrode array [18].

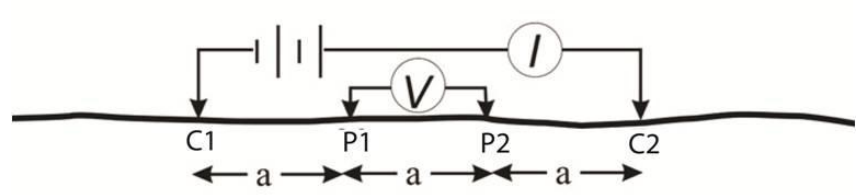

Fig. 2. The Wenner electrode array

\subsection{Seismic refraction method}

The seismic refraction method utilizes seismic signal that returns to the ground surface after travelling through the ground along refracted ray path, which influences the various seismic velocities in difference earth layers. The seismic signal is conducted into the earth's subsurface layers through an energy source point by using hammer, weight dropped, vibrator and explosives [17]. The first arrival of seismic energy was detected by seismic receivers or geophones arranged along ground surface from a seismic source always represents either a direct ray or a refracted ray (Fig. 3).

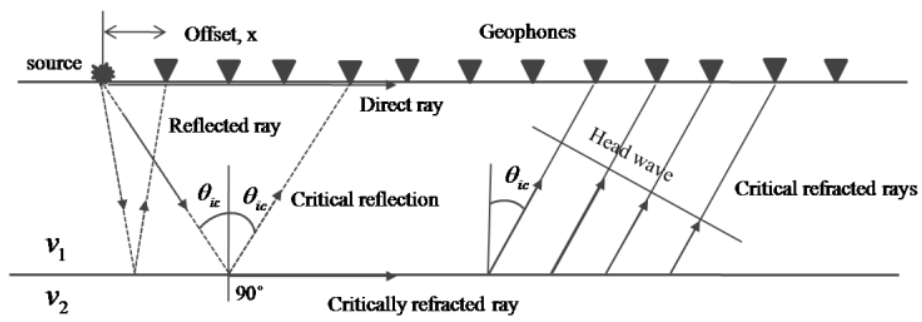

Fig. 3. Seismic ray path of direct, reflection, and refraction waves

The thickness and velocity of earth subsurface layers can be computed by determining the arrival times for direct and refracted waves from seismic signals. The seismic velocities of longitudinal waves, P-wave, $V_{P}$ and of transverse waves, $\mathrm{S}$-wave, $V_{S}$ in a homogeneous and isotropic medium are expressed by the equation (2). Seismic velocities depend on the material properties such as composition, temperature and pressure. Table 2 shows seismic velocity value depends on various earth materials [19].

$$
V_{P}=\sqrt{\frac{\lambda+2 \mu}{\rho}} \text { and } \quad V_{S}=\sqrt{\frac{2 \mu}{\rho}}
$$

Many reports on seismic refraction methods have stated that the seismic velocity values can be used to estimate the depth of the water table or aquifer. However, seismic velocity models have ambiguity for interpretation due to a wide range of seismic velocity values in connection to the water table level and these values are not only uniquely correlated to the aquifer layer but also depends on other factors of earth materials. Some authors have determined seismic velocities about $1500 \mathrm{~m} / \mathrm{s}$ for saturated layers [20]. Meanwhile, another report proposes seismic velocity values vary from 1200 to $1800 \mathrm{~m} / \mathrm{s}$ in 
aquifer layers [21]. Many researchers have been applied the seismic refraction method for the identification of groundwater and structural geology investigations [22-27].

Table 2: The P-wavevelocity of various earth materials [19]

\begin{tabular}{l|c}
\hline \multicolumn{1}{c|}{ Earth materials } & P-wave velocity $(\mathrm{m} / \mathrm{s})$ \\
\hline Air & 331.5 \\
Water & $1400-1600$ \\
Sandstone and shale & $2000-4500$ \\
Limestone & $2000-6000$ \\
Sand and gravel & $500-1500$ \\
Shale & $2000-4500$ \\
Conglomerate & $10-800$ \\
Alluvium & $500-2000$ \\
Sand (Unsaturated) & $200-1000$ \\
Sand (Saturated) & $800-2200$ \\
Clay & $1000-2500$ \\
\hline
\end{tabular}

The Seislmager software was selected to use for seismic refraction data interpretation in this work. This software consists of a system package for picking the first arrival time for P-wave called the PickWin program. All seismic events were picked the first breaks then the arrival times against distance between the shot and geophone positions. The Plotrefa file package was used for the second step of this procedure, which package was used to run the time as an inversion in order to generate the seismic velocity model in term of the thickness of the earth subsurface layers and a seismic velocity value agree with subsurface geological information under the seismic profile [28].

\subsection{Survey profiles}

The eight ERT profiles were carried out at the two sites, including five ERT profiles were conducted the site 1 in Outhomphone district and three ERT profiles were conducted at the site 2 in Champhone district.

The five ERT profiles in Outhomphone district are introduced below, in which there are 4 profiles were oriented in the NE to SW directions, 1 profile left was oriented in the NW to SE directions, maximum length of profile of 440 to $480 \mathrm{~m}$ (Fig 4). The Wenner electrode array was selected to conduct with electrode spacing of $a=10$ up to $160 \mathrm{~m}$. The data were recorded by manually and automatically in the Terrameter ABEM SAS 1000 (Made in Sweden).

The five seismic refraction profiles were conducted at site 1 in Outhomphone district only, used the SmartSeis ST with 12 channels seismograph (Made in USA). The two seismic refraction profiles were conducted on overlies on two selected ERT profiles (2 and 4 ) in the study area will be presented below (Fig 4), seismic profile length of $330 \mathrm{~m}$, with geophone interval of $5 \mathrm{~m}$, and consists of 6 spreads for each seismic profile. In this measurement, consisted of laying out 12 geophones in a straight line and recording arrival times from shot points produced by striking a $6.5 \mathrm{~kg}$ sledge hammer into a steel plate at 7 shots per spread: one inter-spread shot, three forward and three reverse shots (Fig. 5). The first geophones of the first spread placed at $0 \mathrm{~m}$ and the $12^{\text {th }}$ geophone at $55 \mathrm{~m}$; while the first geophone of the second spread located at $55 \mathrm{~m}$ and the $12^{\text {th }}$ geophone at $110 \mathrm{~m}$ then move to next spread until reach to the first geophone of spread 6 placed at $275 \mathrm{~m}$ and the $12^{\text {th }}$ geophone at $330 \mathrm{~m}$. Additionally, two boreholes were drilled at the study area to match, demonstrate and complement the results of integrated ERT and seismic refraction methods.

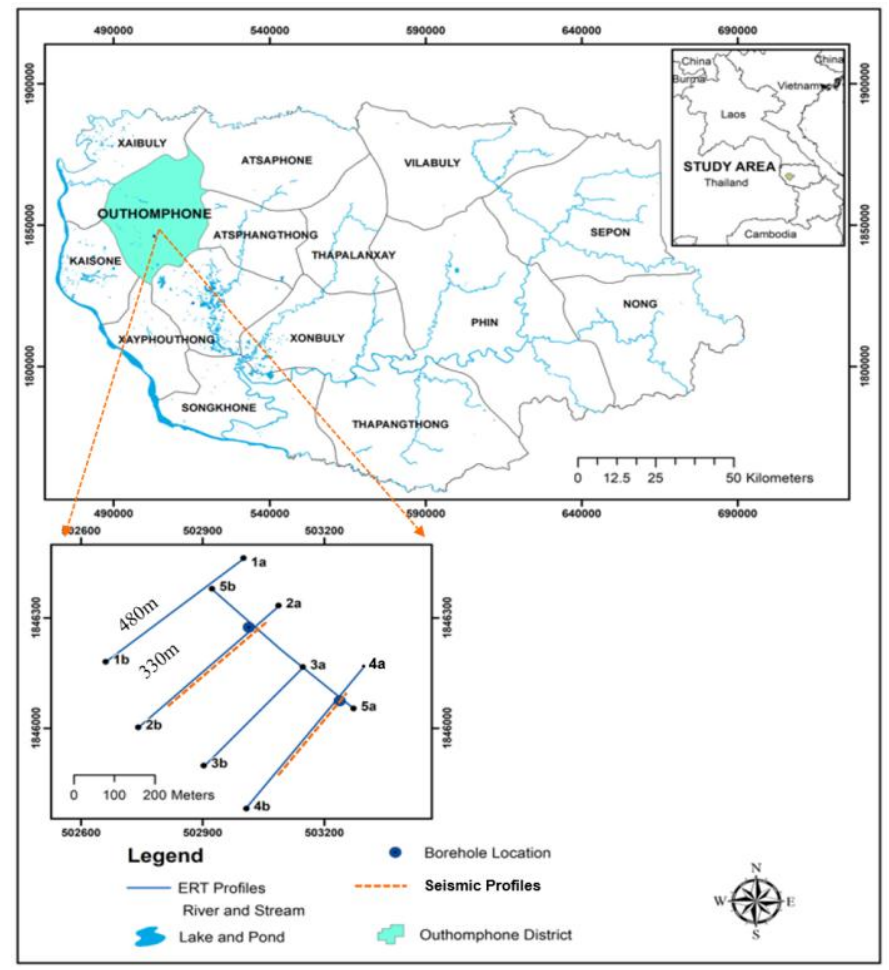

Fig. 4. Maps showing the orientation of ERT and seismic refraction profiles.

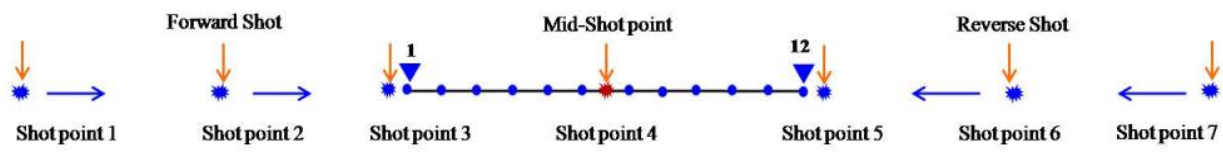

Fig. 5. A typical seismic refraction data acquisition layout and location of shot points for seismic refraction survey profile. 


\section{Results and discussion}

Four parallel NE to SW oriented profiles $(1,2,3$ and 4$)$ at the study area showed similar results (Fig. 6). High resistivity regions greater than $100 \mathrm{Ohm} . \mathrm{m}$ found at 15$80 \mathrm{~m}$ depth along these profiles with unclear thickness are considered as sandstone or bedrocks layers of these profiles. The relatively low resistivity regions less than 10 Ohm.m appear at some zones for each profile with unclear thickness are considered to be a thick clay zone. However, moderate resistivity values of 15 to 60 Ohm.m are observed at 16 to $80 \mathrm{~m}$ depth along these profiles are interpreted to be appropriate groundwater potential zones. In order to correlate the positions of the earth subsurface layers in research site, a fifth profile (profile 5) was arranged crossing the two parallel profiles (2 and 4 ) in an ES to WN direction, with crossing points of profiles 2 and 4 at $60 \mathrm{~m}$ and $330 \mathrm{~m}$ respectively (Fig. 7). High resistivity values greater than $100 \mathrm{Ohm} . \mathrm{m}$ found at $10-80 \mathrm{~m}$ depth, distances between 0 and $160 \mathrm{~m}$ at the depths of unclear, is considered as sandstone or bedrocks layers of the profile. The relatively low resistivity regions less than 10 Ohm.m appear at some zones for this profile with unclear thickness are considered to be a thick clay zone. However, moderate resistivity regions of 15 to $60 \mathrm{Ohm} . \mathrm{m}$ are observed at 18 to $80 \mathrm{~m}$ depth along these profiles are interpreted to be suitable groundwater potential zones.

In addition, two seismic refraction profiles (1 and 2) were conducted at over lied on selected ERT profiles (2 and 4), the starting point of seismic profile located at $55 \mathrm{~m}$ of ERT profiles while the end of seismic profile located at $385 \mathrm{~m}$ of ERT profile (Fig. 8). The results of both two seismic profiles (1 and 2) were well correlated with 2D geoelectric cross section of ERT profiles 2 and 4. The ERT and seismic results show moderate resistivity values of 15 to $60 \mathrm{Ohm} . \mathrm{m}$ and seismic velocity range from 1200 to 1800 $\mathrm{m} / \mathrm{s}$ are considered to be the water table at depth of about $16-20 \mathrm{~m}$. The low resistivity regions less than $10 \mathrm{Ohm} . \mathrm{m}$ and seismic velocity range from 800 to $1200 \mathrm{~m} / \mathrm{s}$ are interpreted to be a thick clay zone (with unclear thickness), whereas high resistivity regions greater than $100 \mathrm{Ohm} . \mathrm{m}$ and seismic velocity greater than $1800 \mathrm{~m} / \mathrm{s}$ are interpreted as sandstone or bedrocks subsurface earth layers.

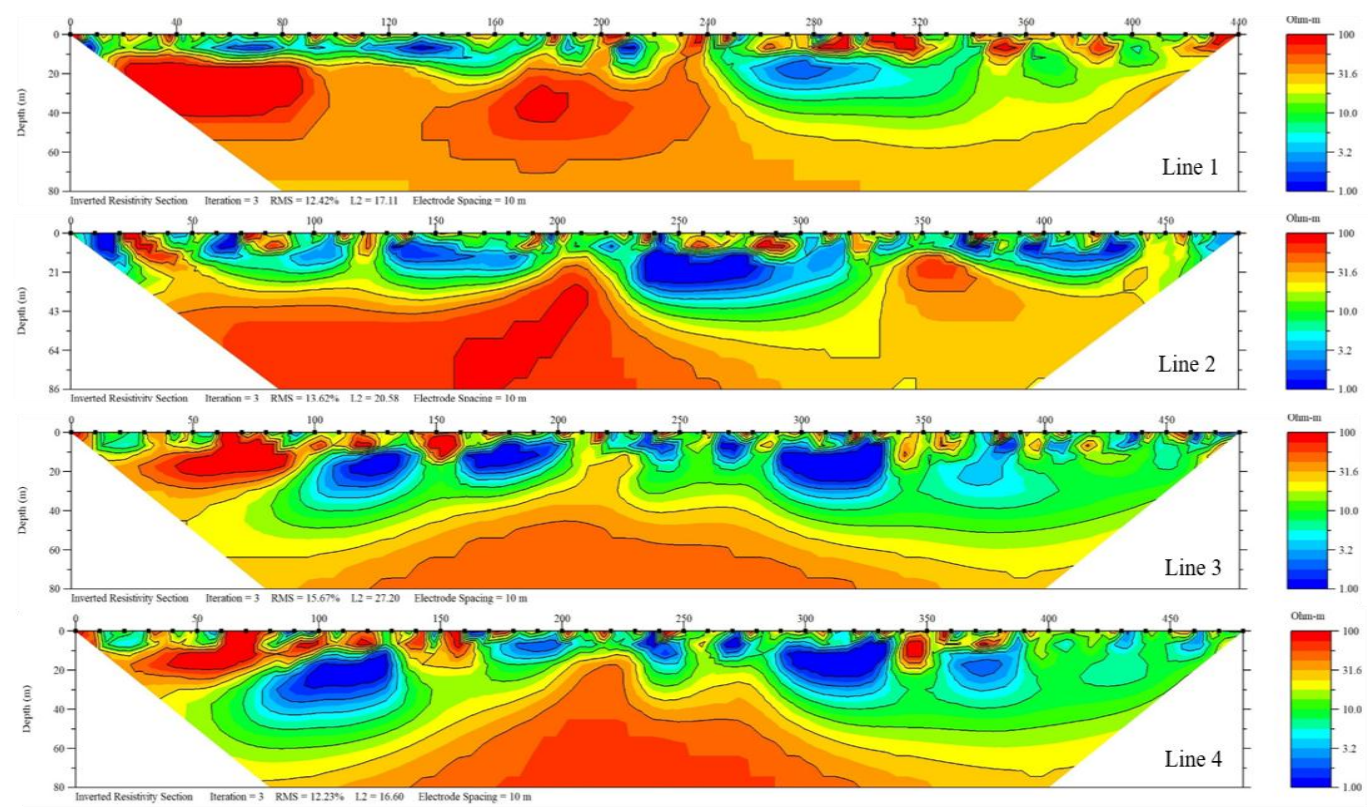

Fig. 6. 2D geoelectric cross sections at profiles 1, 2, 3 and 4 .

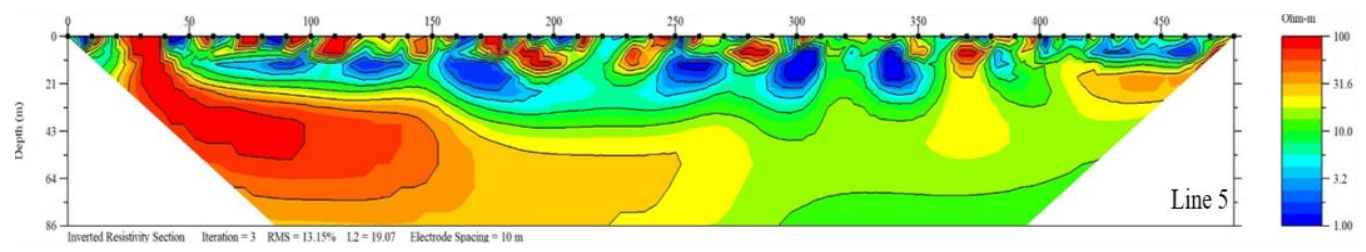

Fig. 7. 2D geoelectric cross section at profile 5 . 


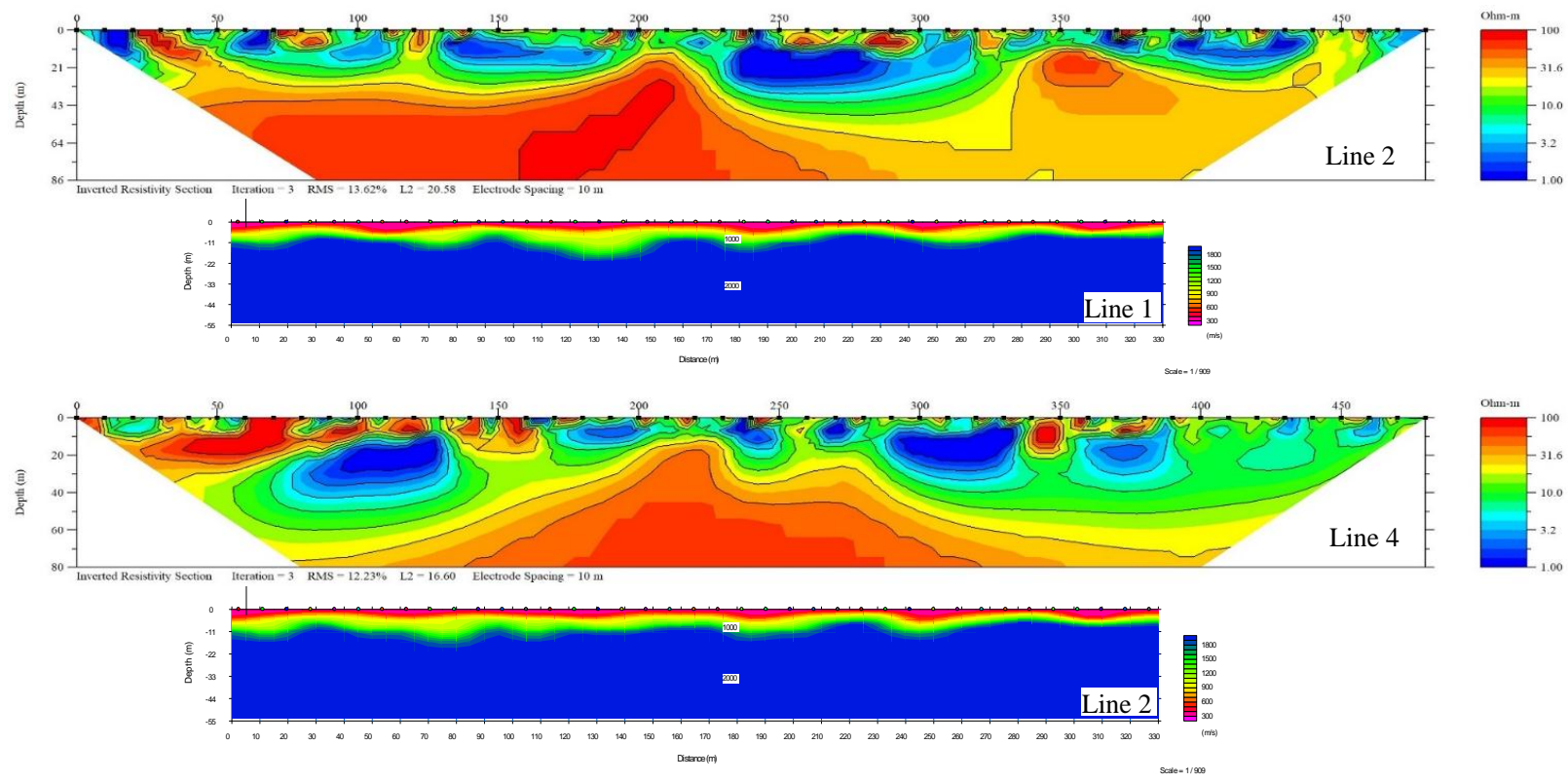

Fig. 8. 2D geoelectric cross sections at profiles 2 and 4 versus seismic velocity models at profiles 1 and 2 .

In order to match electrical resistivity and seismic results, two boreholes were drilled at $100 \mathrm{~m}$ along ERT profiles $(2,4)$ and $45 \mathrm{~m}$ along seismic profiles $(1,2)$ for verifying the positions of water table or aquifers layers (Fig. 9 and 10). The results obtained from the boreholes 1 and 2 $(\mathrm{BH}-1$ and $\mathrm{BH}-2)$ showed the water table at about $16 \mathrm{~m}$ depth for borehole 1 and $20 \mathrm{~m}$ depth for borehole 2 . The soil samples collected from both two boreholes have been classified as sandstone and siltstone at water table level (Fig. 9c and 10c), which respond well for electrical resistivity regions of 15 to $60 \mathrm{Ohm} . \mathrm{m}$ (Fig. 9a and 10a) and seismic velocity range from 1200 to $1800 \mathrm{~m} / \mathrm{s}$ were identified for groundwater potential zones (Fig. $9 \mathrm{~b}$ and 10b).

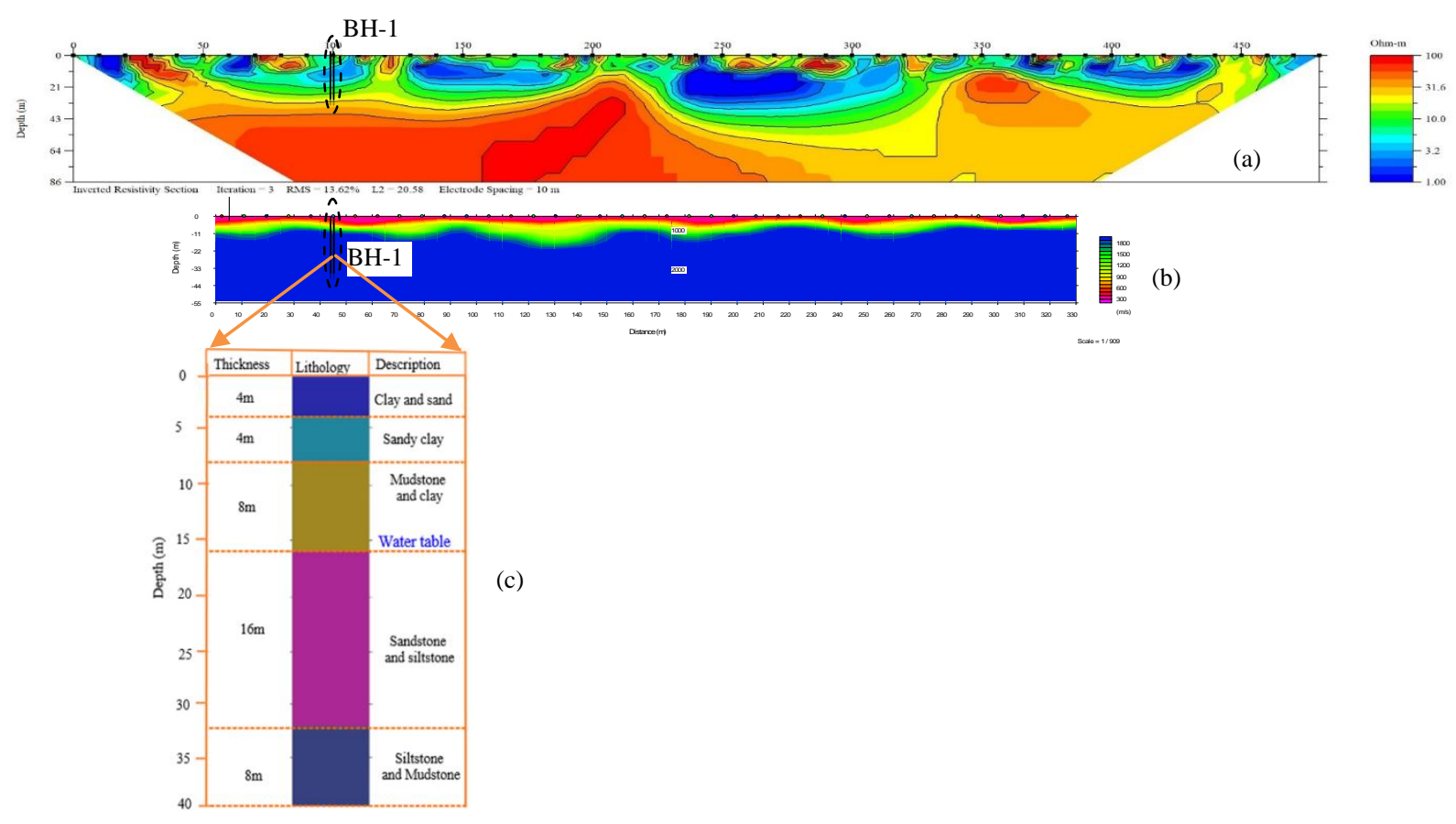

Fig. 9. (a) 2D geoelectric cross section at profile 2, (b) The seismic velocity models at profile 1, (c) vertical geological section of borehole $1(\mathrm{BH}-1)$ at $100 \mathrm{~m}$ along ERT profile 2 and $45 \mathrm{~m}$ along seismic profile 1 . 


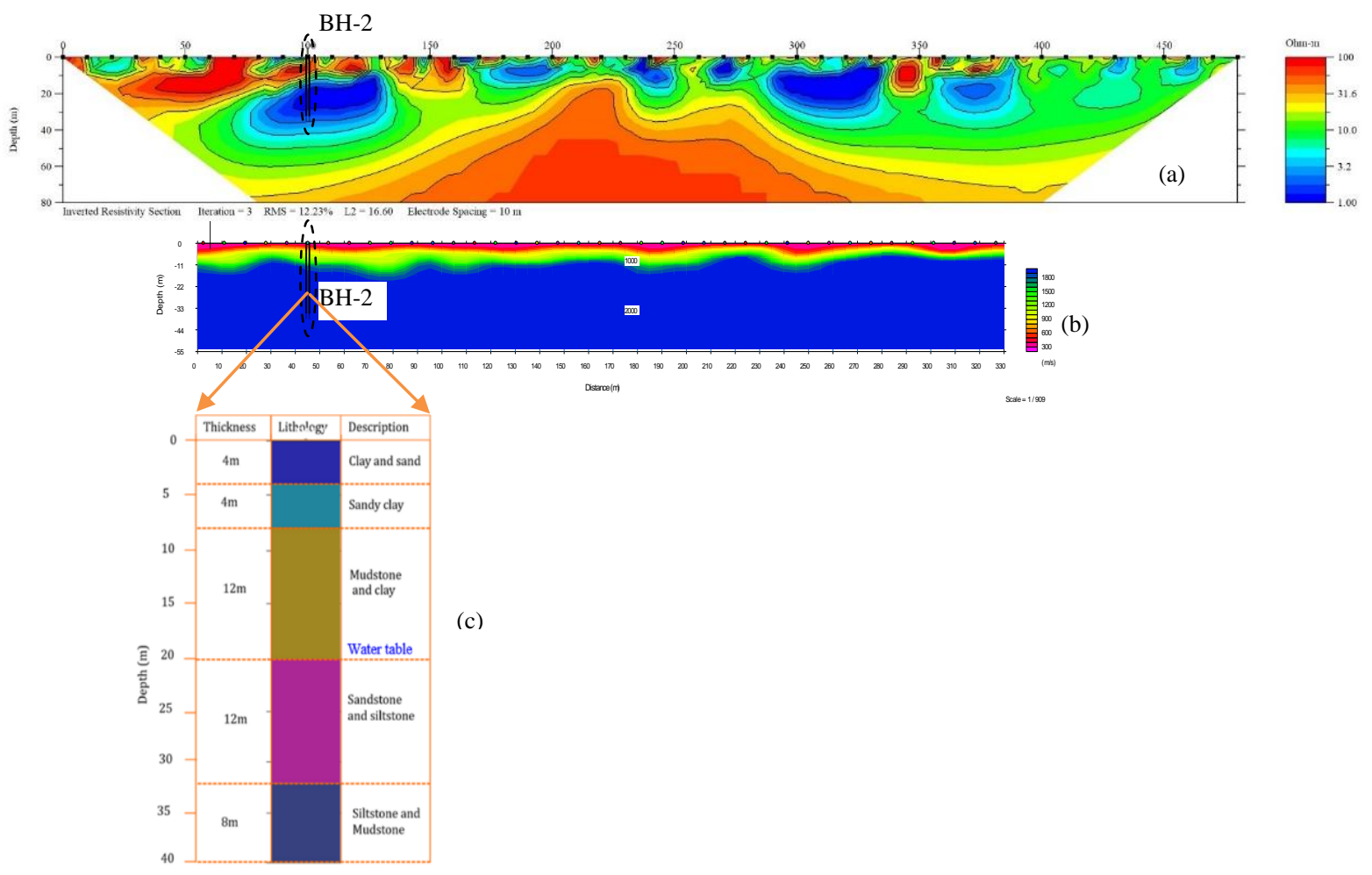

Fig. 10. (a) 2D geoelectric cross section at profile 4, (b) The seismic velocity models at profile 2, (c) vertical geological section of borehole $2(\mathrm{BH}-2)$ at $100 \mathrm{~m}$ along ERT profile 4 and $45 \mathrm{~m}$ along seismic profile 2 .

\section{Conclusion}

The results obtained from this study showed that the relatively low resistivity regions less than $10 \mathrm{Ohm} . \mathrm{m}$ and seismic velocity regions of 300 to $800 \mathrm{~m} / \mathrm{s}$ are considered as clay layers; high resistivity regions greater than 100 Ohm.m and seismic velocity greater than $1800 \mathrm{~m} / \mathrm{s}$ are interpreted as sandstone or bedrocks layers, and the moderate resistivity regions of 15 and $60 \mathrm{Ohm} . \mathrm{m}$, whereas seismic velocity regions of 1200 to $1800 \mathrm{~m} / \mathrm{s}$ found at 16 to $20 \mathrm{~m}$ depth are considered as water table, indicating water table that correlates well with groundwater table from borehole information in the study area. The examples outlined in the text demonstrate that the simultaneous application of the electrical resistivity tomography and seismic refraction exploration methods to identify groundwater is feasible and effective. These results will also be useful for assessment and groundwater investigation and can be applied for groundwater investigation in other similar geological areas in Lao PDR.

\section{Acknowledgments}

We would like to thanks to the International Programme in the Physical Science (IPPS) of Uppsala University, Sweden and International Center of Physics, Institute of Physics, Vietnam, Grant number ICP.2019.09 for research grant supporting in this research work. The authors would like to express our deepest appreciation to Department of Physics, Faculty of Natural Sciences, National University of Laos for supporting the geophysical equipment and Department of Geology and Mines of Laos for geological information in the study areas. Special thanks to Mr. Thiengsamone Sounsuandao and BSc. students from Department of Physics, Faculty of Natural Sciences, National University of Laos for the hard fieldwork assistance.

\section{References}

[1] Medlicott, K., (2001). Water sanitation and environemtal health in rural Lao PDR, KAP study for UNICEF, WES Section.

[2] Takayanagi, K. (1993). Basic Design Study Report on the Project for Groundwater Development in Vientiane Province in Lao PDR. Japan International Cooperation Agency (JICA).

[3] Knudsen, J.R. (2004). The online Support and Training Project for Groundwater Sector of Lao PDR, 434-437.

[4] Dahlin, T., Leroux, V., Nissen J. (2002). Measuring Techniques in Induced Polarization Imaging. Journal of Applied Geophysics 50(3), 279-298.

[5] Vu, M.D, Xayavong, V., Do, C.A, Pham, L.T, GómezOrtiz, D., Eldosouky, A.M. (2021). Application of the improved multielectrode electrical exploration methods for groundwater investigation in Vientiane Province, Laos. Journal of Asian Earth Sciences: X 5, 100056.

[6] Kafadar, O. (2020). A geophone-based and low-cost data acquisition and analysis system designed for microtremor measurements. Geosci. Instrum. Method. Data Syst. 9, 365-373.

[7] Kafadar, O. (2021). RaspMl: Raspberry $\mathrm{Pi}$ Assisted Embedded System for Monitoring and Recording of Seismic Ambient Noise. IEEE Sensors Journal 21(5), 6306-6313.

[8] Saad, R., Syukri, M., Nordiana, M.M., Ismail, N.A. (2013). Water table Delineation for Leachate Identification using 2-D Electrical Resistivity Imaging (2-DERI) and Seismic Refraction at Gampong Jawa, Banda Aceh. Electronic Journal of Geotechnical Engineering 18, 1529-1535. 
[9] Ronczka,M., Hellman, K., Günther, T., Wisén, R., Dahlin, T. (2017). , Electric resistivity and seismic refraction tomography: a challenging joint underwater survey at Äspö Hard Rock Laboratory. Solid Earth 8, 671-682.

[10] Saad, R., Muztaza, M.N., Zakaria, M.T., Saidin, M.M., (2017). Application of 2D Resistivity Imaging and Seismic Refraction Tomography to Identify Sungai Batu Sediment Depositional Origin. Journal of Geology \& Geophysics 6, 1-5.

[11] El Tabakh M., Utha-Aroon, C., Chreiber, B.C. (1999). Sedimentology of the Cretaceous MahaSarakham evaporites in the Khorat Plateau of northeastern Thailand. Sedimentory Geology 123, 31-62.

[12] Stuart-Fox, M., Rooney, D.F. (2006). Microsoft Encarta.

[13] Hite, R.J., Japakasert, T. (1979). Potash deposits of the Khorat Plateau, Thailand and Laos. Economic Geology 74(2), 448-458.

[14] Keith, S., Crosby, P. (2005). Overview of the Geology and Resources of the APPC Udon Potash (Sylvinite) Deposits, Udon Thani Province, Thailand, International Conference on Geology, Geotechnology and Mineral Resources of Indochina (GEOINDO 2005), Khon Kean, Thailand, 283-299.

[15] Cantanont T., Srisuk, K. (2005). Determination of Groundwater Recharge at Nong Bo Area, Maha Sarakham Province, Thailand, International Conference on Geology, Geotechnology and Mineral Resources of Indochina, 143-148.

[16] Jenkunawat, P. (2005). Results of of Drilling to Study Occurrence of Salt Cavities and Surface subsidence Ban Non Sabaeng and Ban Nong Kwang Ampoe Ban Muang, Sakon Nakon. International Conference on Geology, Geotechnology and Mineral Resources of Indochina (GEOINDO 2005), Khon Kaen, Thailand, 259-267.

[17] Reynold, J.M. (2002). An Introduction to Applied and Environmental Geophysics. Wiley (Eds.), England.

[18] Loke, M.H., Barker, R.D. (1996). Rapid least-squares inversion of apparent resistivity pseudosections by a quasiNewton method. Geophysical Prospecting, 44, 131-152.

[19] Kearey, P. Brooks, M., Healy, I. (2002). An Introduction to Geophysical Exploration, 3rd ed. Blackwell Science.

[20] Grelle, G., Guadagno, F.M. (1969). Seismic refraction methodology for groundwater level determination: "Water seismic index", Journal of Applied Geophysics, 68, 2009, 301-320.

[21] Hasselstroem, B. (1969). Water prospecting and rockinvestigation by the seismic refraction method. Geoexploration 7(2), 213.

[22] Amir, G., Ahmed M., Haydar B., Khalid, B., Hasan, A., Saber, M. (2012). The use of seismic refraction and electrical techniques to investigate groundwater aquifer, wadi al-ain, United Arab Emirates (UAE), Conference Proceedings, Tulcea Romania.

[23] Thomas, S., Benjamin, W., Anne, A. S., (2013). Case study of a geophysical investigation with seismic refraction tomography and the Ohm Mapper to estimate the brine content of a Salar/Salmuera. Near Surface Geoscience, 31, 85-90.

[24] Osumeje, J.O., Kudamnya, E.A. (2014). Hydro-geophysical Investigation Using Seismic Refraction Tomography to Study the Groundwater Potential of Ahmadu Bello University Main Campus, within the Basement Complex of Northern Nigeria. Journal of Environment and Earth Science 4(2), 15-22.
[25] Adewoyin, O.O., Joshua, E.O., Akinyemi1, M.L. (2016). Application of Shallow Seismic Refraction Method and Geotechnical Parameters in Site Characterization of a Reclaimed Land, Indian Journal of Science and Technology, 9(45), 1-7.

[26] Anomohanran, O. (2012). Geophysical interpretation of seismic reflection data obtained from Umureute and Amiynaibo area of Delta state, Nigeria, Nigerian. J. Sci. Environ. 11, 148153.

[27] Bery, A.A. (2013). High Resolution in Seismic Refraction Tomography for Environmental Study. International Journal of Geosciences 4, 792-796.

[28] Adedibu, S.A., Abimbola, C.O. (2019). Insight into seismic refraction and electrical resistivity tomography techniques in subsurface investigations. The Mining-Geology-Petroleum Engineering Bulletin 34(1), 93-111. 